\title{
PARAFIA POD WEZWANIEM WSZYSTKICH ŚWIĘTYCH I NIEPOKALANEGO POCZĘCIA NMP W GROCHOLICACH W ŚWIETLE WIZYTACJI KANONICZNYCH
}

\begin{abstract}
Streszczenie
Parafia w Grocholicach należy do najstarszych w archidiecezji łódzkiej i starszych w Polsce. Przyjmuje się, że parafia pw. Wszystkich Świętych i Niepokalanego Poczęcia Najświętszej Marii Panny została erygowana ok. 1230 r. przez ówczesnego arcybiskupa gnieźnieńskiego Wincentego z Niałka herbu Jeleń. Najstarsze zachowane dokumenty z wizytacji parafii w Grocholicach przechowywane są w Archiwum Diecezjalnym we Włocławku i pochodzą z 1636 oraz 1683 r. W niniejszym opracowaniu wykorzystano materiały z XVII, XVIII i pierwszej połowy XIX w. Pierwotny kościół wybudowano z kamieni polnych i cegły ok. 1233 r. Zabytkowa świątynia został rozebrana na początku XX w., a na jej miejscu wzniesiono nowy obiekt w stylu neogotyckim.
\end{abstract}

Słowa kluczowe: Bełchatów; Grocholice; parafia; wizytacje

Parafia w Grocholicach z całą pewnością zalicza się do najstarszych w archidiecezji łódzkiej i starszych w Polsce, chociaż jej początki są niezbyt jasne i toną w tzw. ,pomrokach dziejów”. Do czasu reformy administracyjnej kościoła na zie-

*Aleksy Piasta - dr historii; starszy kustosz w Archiwum Państwowym w Piotrkowie Trybunalskim; e-mail: alekpiasta@gmail.com

https://orcid.org/0000-0003-2228-5409

${ }^{1}$ Najstarsze parafie na ziemiach polskich powstały na przełomie XII i XIII w., chociaż historycy nie są zgodni, czy miało to miejsce w XII, czy dopiero XIII w. Przed 1939 r. opowiadano się raczej za tym drugim okresem, np. W. Abraham. Obecnie panuje pogląd, że miało to miejsce już pod koniec XII w. Stan badań nad dziejami parafii w Polsce przedstawił E. Wiśniowski, który tak podsumował dyskusję i powstałe w jej trakcie kontrowersje: „Dokonany przegląd stanowisk pozwala stwierdzić, że jedną z przyczyn rozbieżności są różnice w pojmowaniu parafii. Ci, którzy istotę jej upatrują czy to w wyraźnie zakreślonym okręgu czy też w elementach jurysdykcyjnych, widzą początki parafii dość późno, ci zaś, którzy kładą nacisk na funkcjonowanie powstających kościołów - znacznie wcześniej”. Zob. E. Wiśniowski, Badania nad początkami i rozwojem średniowiecznej sieci parafialnej na ziemiach polskich, „Annales Universitatis Mariae Curie-Skłodowska Lublin - 
miach polskich, jaką przeprowadzono w drugim dziesięcioleciu XIX w., parafia należała do dekanatu szadkowskiego, archidiakonatu uniejowskiego $\mathrm{w}$ archidiecezji gnieźnieńskiej. Dobra grocholickie wchodziły w skład tzw. klucza kluckiego i należały do dóbr stołowych arcybiskupów gnieźnieńskich. Po 1818 r. Grocholice znalazły się w granicach dekanatu piotrkowskiego i nowo powstałej diecezji kujawsko-kaliskiej. Aktualnie przyjmuje się, że parafia pw. Wszystkich Świętych i Niepokalanego Poczęcia Najświętszej Marii Panny (tej drugiej tytulatury używano znacznie rzadziej) została erygowana ok. 1230 r. przez ówczesnego arcybiskupa gnieźnieńskiego Wincentego z Niałka herbu Jeleń. Część dawniejszych historyków kościoła (m.in. ks. Jan Korytkowski) ulegając sugestii Jana Długosza, widziała w arcybiskupie Wincentym przedstawiciela możnego rodu Nałęczów (miał to być rzekomo Wincenty z Czarnkowa herbu Nałęcz)².

Sprawozdania z wizytacji kanonicznych stanowią najcenniejsze źródło do badań dziejów terenowych struktur administracji kościelnej ${ }^{3}$. Najstarsze zachowane dokumenty z wizytacji parafii w Grocholicach przechowywane są w Archiwum Diecezjalnym we Włocławku i pochodzą z 1636 oraz $1683 \mathrm{r}^{4}$. W niniejszym opracowaniu wykorzystano materiały z XVII, XVIII i pierwszej połowy XIX w. ${ }^{5}$

Kościół w Grocholicach, prawdopodobnie zakończono budować ok. 1233 r., już po śmierci fundatora, arcybiskupa Wincentego z Niałka ${ }^{6}$. Świątynia składała się z prostokątnej nawy o długości $11,5 \mathrm{~m}, \mathrm{z}$ drewnianym sufitem oraz niższego i węższego prezbiterium o wymiarach $7 \times 5 \mathrm{~m}$. W przeciwieństwie do nawy prezbiterium posiadało murowane sklepienie z kopułą. Dach kryty był gontami, nie było dużej wieży, a jedynie sygnaturka. Od północnej strony, przy prezbiterium dobudowano zakrystię, a od południa do nawy niewielką kruchtę ${ }^{7}$ (prawdopodobnie w XIX w.). Kościół był kilkakrotnie remontowany, mimo to nie zatracił swojego pierwotnego wyglądu aż do gruntownej rozbudowy jaka się dokonała na przełomie XIX i XX stulecia.

Polonia”, 45 (1990) s. 43-55; W. Abraham, Organizacja kościoła w Polsce do połowy XII wieku, Lwów 1890, s. 160; R. Kufel, Kancelaria, registratura i archiwum parafialne na ziemiach polskich od XII do początku XXI wieku, Zielona Góra 2011, s. 27.

${ }^{2}$ Szerzej na temat tego nieporozumienia pisał ks. Józef Umiński w artykule zamieszczonym w księdze pamiątkowej poświęconej Władysławowi Abrahamowi, a opublikowanej we Lwowie w 1931 r. Zob. J. Umiński, Arcybiskup Wincenty z Niałka, następca Henryka, zw. Kietliczem, w: Księga pamiątkowa ku czci Władysława Abrahama, t. 2, Lwów 1931, s. 137-166. Zob. też. J. Korytkowski, Arcybiskupi gnieźnieńscy, prymasowie i metropolici polscy, t. 1, Poznań 1888, s. 343-361.

${ }^{3} \mathrm{O}$ znaczeniu tego typu dokumentacji źródłowej pisze: A. Hamryszczak, Canonical visitations as a historical source, „Archiwa, Biblioteki i Muzea Kościelne”, 105 (2016) s. 53-62.

${ }^{4}$ Archiwum Diecezjalne we Włocławku (dalej: ADWł), Visitationes ecclesiarum archidiaconatus unieioviensis (dalej: Visitationes), sygn. AAG, wiz. 5, s. 180-183 i AAG, wiz. 8, s. 122-127.

${ }^{5}$ ADW , Visitationes, sygn. AAG, wiz. $5 ; 8 ; 9 ; 13 ; 41 ; 59 ; 72 ; 81 ; 135$.

${ }^{6}$ Autorzy Stownika geograficznego..., podają, że kościół był fundowany w 1223 r. Por. Słownik geograficzny Królestwa Polskiego i innych krajów słowiańskich, red. F. Sulimierski, B. Chlebowski, W. Walewski, t. 2, Warszawa 1881, s. 811-812.

${ }^{7}$ Zabytki sztuki w Polsce. Inwentarz topograficzny. Powiat Piotrkowski. Praca zbiorowa uczestników obozu naukowego w Sulejowie k. Piotrkowa, Warszawa 1950, s. 88-93. 
Arcybiskup Wincenty z Niałka pełnił swój urząd w latach 1220-1232. Należy tu jednak wspomnieć, że dopiero w wieku XIX data fundacji parafii oraz budowy kościoła pojawiła się w oficjalnych źródłach. Na podstawie tych wzmianek nie jest możliwe ustalenie, na jakim źródle pierwotnym opierano tak starożytną metrykę Grocholic. Najstarsze zapisy odnoszące się do parafii i jej uposażenia, przede wszystkim Liber beneficiorum ${ }^{8}$ prymasa Jana Łaskiego z roku 1521, jak i późniejsze protokoły wizytacyjne (np. z 1636 i 1683), nie podają daty erygowania parafii i kościoła. Niektóre milczą na ten temat (Łaski), bądź stwierdzają enigmatycznie, że nie wiadomo kto, ani też kiedy to uczynił ${ }^{9}$. Nie znano też daty konsekracji świątyni, którą poświadczały wizerunki znaków krzyżowych na murach. Trwałym dowodem konsekracji był zwyczaj świętowania pierwszej niedzieli po dniu św. Bartłomieja (24 sierpnia), jako dnia konsekracji kościoła. Dopiero po upadku I Rzeczypospolitej, 7 maja 1796 r. arcybiskup gnieźnieński i wybitny polski poeta, Ignacy Krasicki wydał akt erekcyjny dla kościoła parafialnego w Grocholicach ${ }^{10}$. Można przypuszczać, że działania te wynikały z aktualnej potrzeby ponownej lustracji majątku kościelnego. Pierwotny akt erekcyjny zaginął $i$ nie znano jego treści. Wiedza dziewiętnastowiecznych autorów wskazujących na średniowieczny rodowód kościoła w Grocholicach, nie musiała wcale być pozbawiona podstaw ${ }^{11}$. Jak podaje ks. Henryk Rybus we wstępie do regestów akt arcybiskupów gnieźnieńskich opublikowanych w półroczniku „Archiwa, Biblioteki i Muzea Kościelne", archiwum podręczne arcybiskupów gnieźnieńskich przechowywane było od czasu prymasa Jana Łaskiego w pałacu arcybiskupim w Łowiczu $^{12}$. Dopiero arcybiskup Zygmunt Szczęsny Feliński (1862-1883) przeniósł je do swojej siedziby w pałacu arcybiskupim w Warszawie. Tam, aż do drugiej wojny światowej dostępne było badaczom. Mogły się w nim znajdować najstarsze dokumenty odnoszące się do kościoła w Grocholicach. Nie są one jednak dostępne dla badaczy, gdyż poza wspomnianymi regestami, całe Archiwum Kurii Archidiecezjalnej w Warszawie, wraz z aktami gnieźnieńskim, zostało spalone podczas powstania warszawskiego.

Potwierdzeniem dawnej, bo trzynastowiecznej fundacji kościoła mogą być $\mathrm{z}$ dużą dozą prawdopodobieństwa informacje zawarte w dokumentach sporządzonych w początku XIX w. przez ówczesnego proboszcza grocholickiego ks. Tomasza Kafarskiego ${ }^{13}$. Zostały one bezpośrednio wpisane do ksiąg metrykalnych, jak

\footnotetext{
${ }^{8}$ J. Laski, Liber beneficiorum, t. 1, Gniezno 1880, s. 458-459.

${ }^{9}$ Autorzy, którzy podają, że prymas Łaski wskazał nazwisko fundatora świątyni, zdają się zapominać, że informacja ta pochodzi z aparatu naukowego (przypisów) wykonanych przez późniejszego o kilka wieków historyka ks. Jana Korytkowskiego.

${ }^{10}$ Regesty wybranych zapisek z akt działalności arcybiskupów gnieźnieńskich, wyd. ks. H. Rybus „Archiwa, Biblioteki i Muzea Kościelne”, 3 (1961) z. 1-2, s. 400. Odpis aktu erekcyjnego przechowywany był jeszcze w $1861 \mathrm{r}$. w drewnianej skrzyni z dokumentami w archiwum parafialnym.

${ }^{11}$ Por. Ordo divini officii ad usum dioecesis vladislaviensis seu calissiensis, Warszawa 1878 , s. 117.

${ }^{12}$ Regesty wybranych zapisek, s. 113.

13 Zob. https://www.familysearch.org/ark:/61903/3:1:3Q9M-CSXK-Q9FL-K?i=716\&cat=299028 (dostęp: 13.11.2018). Jako pierwszy na ślad tych dokumentów natrafił historyk Marek Jasiński, który po-
} 
to się często zdarzało w okresie staropolskim ${ }^{14}$. Materiały mają formę sprawozdania z prac związanych z odbudową kościoła, prowadzonych przez proboszcza od 1788 r. Do tego autor dołączył jeszcze inwentarz majątku parafialnego opisujący wszystkie nieruchomości i ruchomości. Na marginesie opisu wielkiego ołtarza, ksiądz zapisał niezwykle cenną informację, rzutującą na czas budowy pierwotnej świątyni. Otóż zauważył, że na figurze Chrystusa Ukrzyżowanego, stanowiącej element ołtarza umieszczono date 1232. Ten sam rok był wymalowany na belce tęczowej. Poza tym wycięto ją także w drewnie na chórze ${ }^{15}$. Ktokolwiek umieścił te daty, zdawał sobie sprawę z ich znaczenia i pragnął by zachowały się w pamięci potomnych, prawdopodobnie jako daty wzniesienia kościoła. Raczej nie chodziło o konsekrację, ponieważ takowej dokonywano kilka, kilkanaście, a nawet kilkadziesiąt lat po zakończeniu budowy. Dysponujemy więc dwoma bardzo podobnymi datami - 1232 i 1233 r., która jest właściwa? Odpowiedź na to pytanie w tym przypadku, wobec niewielkiej rozbieżności, wydaje się być mniej istotna.

Duże zamieszanie w naszej wiedzy na temat początków parafii wywołały protokoły wizytacyjne archidiakonów uniejowskich, którzy zlustrowali Grocholice w roku 1779 i 1788. Pierwszy z nich napisał, że budowniczym kościoła był arcybiskup gnieźnieński Andrzej Róża Boryszewski. Fakt ten miał być dokonany przed $1500 \mathrm{r}^{16}$. Zapis powtórzył prawie dosłownie wizytator w $1788 \mathrm{r}^{17}$. Cóż takiego nowego odkryto wówczas w archiwach kościelnych, że obaj zdobyli wiedzę obcą swoim poprzednikom i następcom? Swoich stwierdzeń nie oparli na żadnych poświadczonych dokumentach. Czytając dokładnie opis Grocholic pozostawiony przez prymasa Łaskiego, można odnaleźć źródło tej osiemnastowiecznej mistyfikacji. Otóż, już w pierwszym zdaniu prymas napisał, że w mieście Grocholice znajdował się kościół parafialny pw. Wszystkich Świętych, pozostający pod opieką arcybiskupstwa gnieźnieńskiego, który wtedy dzierżył Tomasz Woźnicki (proboszcz), wyznaczony na ten urząd przez arcybiskupa Andrzeja Różę, poprzednika Łaskiego ${ }^{18}$. Wystarczyło niedokładnie odczytać ten zapis i omyłkowo przyjąć, że był on fundatorem kościoła.

informował o swoim odkryciu na blogu we wpisie z dnia 4. 10. 2017 r. Księga metrykalna zawierająca sprawozdanie ks. Kafarskiego została w latach 80. XX w. zmikrofilmowana przez mormonów z USA i opublikowana w internecie. Ks. Tomasz Stanisław Kafarski (†22.08.1813 r.) był proboszczem w latach 1788-1813. M. Różański, Duchowieństwo parafialne archidiakonatu uniejowskiego w XVIII wieku. Studium prozopograficzne, Łódź 2010, s. 337.

${ }^{14}$ Szerzej na temat wykorzystywania przez proboszczów rejestrów akt metrykalnych jako substytutu ksiąg wieczystych pisali: K. Dobrowolski, Znaczenie metryk kościelnych dla badań naukowych, „Rocznik Towarzystwa Heraldycznego”, 5 (1920) s. 106-108 oraz Z. Wilk-Woś, Nie tylko dla genealogów - akta metrykalne w Archiwum Archidiecezjalnym w Łodzi jako źródło do badań historycznych „Prace i Materiały Historyczne Archiwum Archidiecezjalnego w Łodzi i Muzeum Archidiecezji Łódzkiej”, 9 (2012) s. 123-135.

15 Zob. https://www.familysearch.org/ark:/61903/3:1:3Q9M-CSXK-Q9FL-K?i=716\&cat=299028 (dostęp: 13.11.2018).

${ }^{16}$ ADWł, Visitationes, sygn. AAG, wiz. 72, s. 421.

${ }^{17}$ Tamże, sygn. AAG, wiz. 81, s. 9.

${ }^{18}$ Laski, Liber beneficiorum, s. 458. 
Jest jeszcze jeden dowód ograniczonego zaufania do osiemnastowiecznych wizytatorów. Arcybiskup Róża nie mógł raczej przed 1500 r. fundować kościoła w Grocholicach ponieważ urząd arcybiskupa w Gnieźnie objął dopiero w 1503 r., po śmierci brata królewskiego, Fryderyka Jagiellończyka ${ }^{19}$. Do tego roku pełnił funkcję biskupa przemyskiego, a jego rodowe włości znajdowały się na Lubelszczyźnie. Przed objęciem sakry arcybiskupiej sprawował jednak różne godności kościelne (kanonik gnieźnieński, krakowski, włocławski, poznański, prepozyt łęczycki) i nie będąc fundatorem kościoła w Grocholicach, mógł go jednak doposażaće ${ }^{20}$.

Jak podaje prymas Łaski w Liber beneficiorum, parafia grocholicka obejmowała rozległy teren dzisiejszego powiatu bełchatowskiego. Należały do niej oprócz miasteczka Grocholice okoliczne wsie: Bełchatów i Bełchatówek, Zdzieszulice (nazywane wówczas Dzieszulicami), Politanice, Binków, Zawadów, Zawady, Łękawa, Wólka (Wola) Łękawska, Wola Dzieszulska (Zdzieszulice Dolne) a także dwie nieistniejące już dzisiaj miejscowości: Wiestków lub Wieszczków (Westhków) oraz Wola Raciborowa. W późniejszych wiekach, w miarę rozwoju sieci osadniczej, w okręgu parafialnym pojawiły się kolejne wsie: Augustynów, Bernardów, Bugaj, Czapliniec, Edwardów, Kalisko, Kałduny, Kielchinów, Kurnos Grocholicki, Księży Młyn, Lipy, Ludwików, Mazury, Nowy Świat, Oleśnik, Olsztyn, Rząsawa, Wawrzkowizna, Zamoście Grocholickie, czy też Zamoście Bełchatowskie.

Proboszcz posiadał w początkach XVI stulecia wystarczające dochody, aby utrzymać na swój koszt wikariusza oraz kościelnego (ministra). Podstawowym źródłem dochodów była dziesięcina opłacana przez chłopów i mieszczan zamieszkujących wioski leżące na terenie parafii. Sytuację komplikował fakt, że część parafian na podstawie dawnych zapisów i przywilejów płaciła dziesięcinę do innych kościołów. Nawet niektórzy grocholiczanie wnosili tę opłatę do proboszcza w Parznie ${ }^{21}$. Dzisiejszych mieszkańców Zawadowa zainteresuje z pewnością, że w księdze arcybiskupa Łaskiego podano imiona dwóch miejscowych kmieci - jednego o przezwisku „Mały Andrzejek” i drugiego o nazwisku „Albert Pyszycowycz" (Pyrzyczewicz?)22.

Kolejnym, nie mniej istotnym fundamentem finansowania były zyski osiągane z pól kościelnych, dzierżawionych miejscowym mieszczanom i chłopom oraz wiejskie przedsiębiorstwa rolno-przemysłowe, przede wszystkim młyny wodne. Wizytacje dóbr arcybiskupstwa gnieźnieńskiego podają informację, że w XVI w.

${ }^{19}$ Arcybiskup Fryderyk Jagiellończyk zasłużył się pamięci mieszkańców Grocholic, ponieważ w dniu 1 stycznia 1495 r. w pałacu arcybiskupim w Łowiczu wydał przywilej dla Grocholic, w którym zatwierdził i rozszerzył dawne przywileje miasta. Zob. Źródła do historii miast łódzkiego okręgu przemystowego w XIX w., oprac. R. Kaczmarek, Warszawa 1958, Opis miasta [Grocholice] sporzadzony przez burmistrza Latkowskiego [w 1820 r.], s. 129.

${ }^{20}$ Głównym dowodem na to, że arcybiskup Boryszewski, nie mógł być fundatorem kościoła w Grocholicach był fakt, że żył w latach 1425-1521, a świątynię wzniesiono w połowie XIII w. Dowód ten nie wystarcza w sytuacji kwestionowania średniowiecznej metryki grocholickiego kościoła.

${ }^{21}$ ADWł, Visitationes, sygn. AAG, wiz. 72, s. 438.

${ }^{22}$ J. Łaski, Liber beneficiorum, s. 459. 
do kościoła w Grocholicach należał m.in. młyn wodny w Klukach ${ }^{23}$. Stan majątku ziemskiego zgromadzonego przez proboszczy, powiększył się teoretycznie dzięki hojności abpa I. Krasickiego. W dniu 29 grudnia 1796 r. wydał on przywilej, w którym darował grocholickiemu kościołowi osadę wójtowską. Jednak administratorzy dóbr kluckich przywłaszczyli sobie te ziemie, a proboszcza nie było stać na kosztowne procesy sądowe ${ }^{24}$.

Na podobne do Liber beneficiorum Łaskiego źródło informacji na temat parafii grocholickiej przyszło czekać do roku 1636, kiedy odbyła się wizytacja przeprowadzona przez archidiakona uniejowskiego i proboszcza konińskiego, ks. Łukasza Wilkoszowskiego ${ }^{25}$. Protokół powizytacyjny zawiera dość szczegółowe dane dotyczące kościoła farnego oraz jego wyposażenia i beneficium. Na samym wstępie zaznaczono, że ok. 10 lat wcześniej (a więc w 1626 r.) kościół został poważnie zniszczony podczas pożaru miasta. Ani wizytator ani też proboszcz nie potrafili określić, kto był fundatorem świątyni wykonanej z cegły i kamieni polnych. W prezbiterium znajdował się jeden murowany grób. Właściwy cmentarz zlokalizowano ówczesnym obyczajem wokół kościoła. Prawdopodobnie uszkodzenia spowodowane przez ogień były na tyle poważne, że Najświętszy Sakrament oraz oleje (sprowadzone z dekanatu w Szadku) przechowywano w pobliskim kościele pw. Jana Chrzciciela. Także tam znajdowała się chrzcielnica. Na cmentarzu nie było dzwonnicy ani też kostnicy, które jako wykonane z drewna, musiały spłonąć. Ocalała natomiast figura Męki Pańskiej ufundowana przez miejscowych mieszczan ${ }^{26}$.

Zachowany protokół wizytacyjny spisany przez archidiakona uniejowskiego ks. Andrzeja Pruskiego w 1683 r. przedstawia dokładnie stan świątyni ${ }^{27}$. Podano wówczas patronów trzech ołtarzy w kościele farnym. W ołtarzu głównym pw. Wszystkich Świętych znajdował się dodatkowo obraz Najświętszej Marii Panny (u góry). Jeden z dwóch ołtarzy bocznych poświęcony został właśnie NMP a drugi Aniołom Stróżom. Oba posiadały portatyl (co znaczyło, że były konsekrowane). Przy kościele funkcjonowała szkółka parafialna, której rektorem (nauczycielem) był Franciszek Kostrzewicz ${ }^{28}$. Liczbę komunikujących się parafian określano wówczas na ok. 400 osób ${ }^{29}$.

${ }^{23}$ Wizytacje dóbr arcybiskupstwa gnieźnieńskiego i kapituty gnieźnieńskiej w XVI wieku, wyd. B. Ulanowski, Kraków 1920, s. 436.

${ }^{24}$ Regesty wybranych zapisek, s. 401.

${ }^{25}$ ADW1, Visitationes, sygn. AAG, wiz. 5., s. 180-183.

${ }^{26}$ Tamże, s. 180.

${ }^{27}$ ADWł, Visitationes, sygn. AAG, wiz. 8, s. 122-127.

${ }^{28}$ Tamże, s. 126. Istnienie szkoły parafialnej w Grocholicach potwierdzono już w Liber beneficiorum Jana Łaskiego. Upadek szkolnictwa parafialnego był spowodowany wojnami jakie przetoczyły się przez Rzeczpospolitą w połowie XVII w. Zob. M. Różański, Szkoły parafialne w XVI -XVIII wieku w archidiakonacie uniejowskim, Łódź 2003, s. 36.

${ }^{29}$ ADWł, Visitationes, sygn. AAG, wiz. 8, s. 126. 
Tabela 1. Proboszczowie parafii w Grocholicach w latach 1771-1860

\begin{tabular}{|c|c|c|}
\hline Lp. & Imię i nazwisko & $\begin{array}{c}\text { Okres sprawowania } \\
\text { funkcji }\end{array}$ \\
\hline 1. & Dominik Jan Nepomucen & $1771-1777$ \\
\hline 2. & Fortunat Więckowski & $1778-1788$ \\
\hline 3. & Tomasz Stanisław Kostka-Kafarski & $1788-1813$ \\
\hline 4. & Patrycy Jankowski & $1813-1821$ \\
\hline 5. & Kajetan Ungier & $1821-1832$ \\
\hline 6. & Andrzej Kupczyński & $1832-1860$ \\
\hline
\end{tabular}

Źródło: http://www.parafiagrocholice.pl/duszpasterze/proboszczowie/ (dostęp: 11.02.2020).

Wspominano już wyżej, że grocholicka fara posiadała podwójną tytulaturę. Przeważnie używano wezwania Wszystkich Świętych. Po raz pierwszy dopiero w protokole wizytacyjnym z 1765 r. użyto drugiego określenia - Niepokalanego Poczęcia NMP. W tym też okresie na wyposażeniu kościoła pojawia się czwarty ołtarz pw. św. Rocha ${ }^{30}$.

Funkcję proboszcza grocholickiego, czyli komendarza ${ }^{31}$, pełnił w 1779 r. gwardian klasztoru franciszkanów w Bełchatowie, Fortunat Więckowski. Ks. dr Franciszek Grochowalski, wizytator generalny, który w 1779 r. zawitał do Grocholic, pozostawił dokładny opis zarządzanego przez niego kościoła ${ }^{32}$. Ogólny stan budowli nie wyglądał najlepiej. Mury były popękane i miejscami groziły zawaleniem. Do tego od sklepienia w prezbiterium odpadały tynki. Sufit nad nawą główną wykonany był z surowych i nieheblowanych desek tzw. tarcic, które zgniły. Ubytki wypełniano snopkami słomy. Zawaliło się też sklepienie murowanego grobu, który znajdował się pod wielkim ołtarzem. Chór był tak nadwyrężony, że z obawy o bezpieczeństwo uczestników nabożeństw wyniesiono z niego ośmiogłosowe organy (tzw. pozytyw) i postawiono je w prezbiterium obok ołtarza głównego. Na podłodze nie było posadzki a jedynie nadgniłe deski. Także zakrystia dobudowana z lewej strony prezbiterium wymagała pilnego remontu. Kościół pokryty był gontami, miejscami zgnitymi, uzupełnionymi snopkami słomy. Jedynie sygnaturka obita była białą blachą. Stara drewniana dzwonnica pod-

${ }^{30}$ ADWł, Visitationes, sygn. AAG, wiz. 59., s. 121-122.

${ }^{31}$ Znawca problematyki administracji kościelnej XVIII w. podaje precyzyjniejszą definicję terminu „komendarz”: „W sytuacji, gdy w parafii nie przebywał pleban lub wówczas, gdy parafia wakowała, administracją sakramentów w niej zajmował się komendarz. Z racji sprawowanych zadań duszpasterskich w parafii, komendarza generalnie zaliczać będziemy do rządców parafii, chyba, że z analizy źródeł wynika, że czynność tę czynił, zastępując nieobecnego proboszcza. W literaturze przedmiotu brak jest jednoznacznych odpowiedzi, jaka rolę pełnił komendarz. Jedni badacze zaliczają go do rządców parafii, a inni umiejscawiają go w gronie wikariuszy". Zob. M. Różański, Duchowieństwo parafialne archidiakonatu uniejowskiego, s. 47.

${ }^{32}$ ADWł, Visitationes, sygn. AAG, wiz. 72, s. 421-441. Ks. Grochowalski poświęcił też interesujący akapit, stanowiący przyczynek do powstania wspólnoty żydowskiej w pobliskim Bełchatowie. Dziedzic wybudował dla Żydów osiedlających się w miasteczku budynki czynszowe, w których zamieszkało kilkanaście osób. Nie posiadali oni wtedy jeszcze ani synagogi, ani też kirkutu (cmentarza) czy szkoły religijnej. 
trzymywała pięć niewielkich dzwonów, mocno poobijanych. Nie było ani jednego dużego dzwonu. Poza tym na cmentarzu przykościelnym stała jeszcze drewniana kostnica $^{33}$.

W kościele znajdowały się cztery ołtarze - główny, w którym wisiał obraz Wszystkich Świętych oraz trzy mniejsze (św. Rocha, z freskiem świętego na ścianie; NMP Szkaplerznej i Aniołów Stróżów) ${ }^{34}$.

Na gruncie kościelnym, od południowej strony kościoła stał od dawna budynek szkoły parafialnej, w której nauczał nauczyciel (rektor scholae) oraz organista. Na utrzymanie szkoły przeznaczano procent od sumy 800 zł, podarowanych w 1700 r. przez ówczesnego proboszcza grocholickiego. Pieniądze, za zgodą dziedzica Jerzego Spinka zapisano na dobrach Łękawa. W latach 70. XVIII w. fundusz szkolny został wyczerpany, a szkoła popadła w ruinę i wymagała pilnie odnowienia, czego domagał się wizytator od mieszczan.

Budynek szpitala (przytułku) parafialnego wzniesiono w połowie XVIII w. Budowla była w złym stanie technicznym, ponieważ proboszczowie ze względów oszczędnościowych, nie przeprowadzali bieżących remontów. Szpital posiadał dwie izby zamieszkane przez jednego starszego mężczyznę i trzy równie leciwe kobiety.

Najstarszym bractwem działających przy kościele parafialnym w Grocholicach była konfraternia Szkaplerza Świętego założona na mocy pozwolenia ks. Eliasza Szabłowskiego, prowincjała Zakonu Karmelitów w Krakowie w roku 1680. Bractwo posiadało spore fundusze na swoją działalność w postaci zapisów dokonanych przez ks. Aleksandra Grocholczyka (1000 złotych polskich) i Stanisława Rychłowskiego (800 złotych polskich, zabezpieczonych na dobrach Zdzieszulice $)^{35}$.

Drugie bractwo było pod patronatem Aniołów Stróżów i również powstało w 2. połowie XVII w. Konfraternia czerpała dochody z sum (po 200 złotych polskich) zapisanych przez dziedzica Andrzeja Rychłowskiego i mieszczanina grocholskiego Tomasza Dąbrówkę oraz darowizny młynarza Kazimierza Rogalskiego (30 złotych). Dwa ostatnie zapisy zabezpieczone były na polach należących do T. Dąbrówki. Kiedy jego spadkobiercy nie chcieli spłacać procentów, proboszcz odebrał im ziemię ${ }^{36}$.

Wizytator ks. Grochowalski zainteresował się innymi obiektami sakralnymi. Na terenie parafii Grocholice znajdował się przez ponad dwieście lat klasztor Franciszkanów, erygowany w 1617 r. przez abpa Wawrzyńca Gembickiego, a fundowany przez właścicieli Bełchatowa z rodu Kowalewskich. Przy klasztorze wybudowano najpierw drewniany, a z czasem niewielki murowany kościół w stylu barokowym. Konwent zamieszkiwało w 2. połowie XVIII w. 12 zakonników, wśród których było 2 księży (w 1811 r. ich liczba zmniejszyła się do 3 księży i jednego brata zakonnego) ${ }^{37}$. Uposażeniem klasztoru była wieś Zwierzchów

\footnotetext{
${ }^{33}$ ADWł, Visitationes, sygn. AAG, wiz. 72, s. 423-424.

34 Tamże, s. 427.

35 Tamże, s. 430.

${ }^{36}$ ADW1, Visitationes, sygn. AAG, wiz. 72, s. 431.

${ }^{37}$ ADW1, Visitationes, sygn. AAG, wiz. 135, s. 201-202.
} 
(Wierzchów), gdzie osadzono pięciu rolników uprawiających po połowie łana ziemi (tzw. półrolników) oraz dwóch chałupników dysponujących co najwyżej kilkoma morgami gruntu. Półrolnicy zobowiązani zostali do odrabiania trzech dni pańszczyzny sprzężajnej (wołami) a chałupnicy po dwa dni pańszczyzny pieszej. Zakonnicy żyli skromnie, nie wchodząc w konflikt z duchowieństwem świeckim. Przede wszystkim udzielali posługi we dworze, odwdzięczając się w ten sposób fundatorom. W specjalnych kryptach w podziemiach świątyni spoczywali też zmarli członkowie rodzin dobrodziejów klasztoru, z rodu Kowalewskich i Rychłowskich $^{38}$.

Dziedzic dóbr Łękawa i Kamieńsk, Daniel Spinek w 1773 r. wybudował drewnianą kaplicę w Łękawie, poświęconą pierwotnie św. Józefowi, którego niewielkich rozmiarów podobizna widniała w relikwiarzu umieszczonym w głównym ołtarzu ${ }^{39}$. Tytulaturę zmieniono później na Narodzenia NMP. Kościółek posiadał trzy ołtarze - jeden wielki pw. NMP Łaskawej. W 1779 r. zdołano ukończyć tylko prace rzeźbiarskie. Całość nie była pomalowana ani złocona. Dwa ołtarze boczne także nie zostały jeszcze wykończone i trwały nad nimi prace. Podobnie wewnątrz świątyni trwały prace przy budowie niewielkiej ambony i chóru, na którym ustawiono sześciogłosowe organy (pozytyw). Dach kościoła był kryty gontami, a na środku wznosiła się wieżyczka kryta białą blachą, w której zawieszono dzwon pochodzący najprawdopodobniej z kościoła pw. św. Jana Chrzciciela w Grocholicach: „Wieżyczka także jest wyniesiona nad dachem kościoła, blachą białą obita, w której jest dzwon większy z grocholickiego kościoła, który już teraz upadł [podkreślenie - A.P.]"40. Fundator kościoła wyjednał sobie w roku 1768 zezwolenie papieża Klemensa XIII na budowę kaplicy i odprawianie w niej mszy, potwierdzone następnie przez arcybiskupa gnieźnieńskiego Gabriela Podoskie$\mathrm{go}^{41}$.

W kaplicy posługę kapłańską pełnił mieszkający we dworze kapelan (plebanię dla niego dopiero budowano). W $1779 \mathrm{r}$. funkcję tę pełnił od 9 lat (a więc jeszcze w trakcie budowy kościoła) ks. Piotr Elewski, franciszkanin z Piotrkowa ${ }^{42}$. Właściciele Łękawy i dobroczyńcy miejscowego kościółka bardzo często zapraszali do siebie zakonników z piotrkowskich konwentów bernardynów i franciszkanów,

${ }^{38}$ Zainteresowanych historią Bełchatowa oraz jego głównej świątyni odsyłam do obszernego tekstu autorstwa Arkadiusza Kowalczyka, zamieszczonego na stronie internetowej parafii pw. Narodzenia NMP w Bełchatowie. Zob. http://www.fara-belchatow.pl/historia-parafii (dostęp: 14.11.2018).

${ }^{39} \mathrm{~W} 1931$ r. biskup łódzki Wincenty Tymieniecki wydał dekret erygujący parafię w Łękawie, wydzielonej częściowo z parafii Grocholice. Proboszczowie obu parafii mieli początkowo duże problemy z ustaleniem granic. Dopiero po interwencji Kurii i doprecyzowaniu dekretu erekcyjnego udało się wszystko wyjaśnić. Granica biegła drogą gminną pomiędzy Zawadowem a Rząsawą i dzieliła mieszkańców Wólki Łękawskiej. Szczegóły dekretu biskupiego przedstawiono w obu kościołach podczas mszy św. w dniu 8 listopada 1931 r. Pierwotna modrzewiowa świątynia w Łękawie spłonęła doszczętnie podczas okupacji niemieckiej (26 marca 1941 r.). Zob. Archiwum Archidiecezjalne w Łodzi (dalej: AAŁ), Akta Kurii Łódzkiej (dalej: AKŁ), sygn. 51.

${ }^{40}$ ADWł, Visitationes, sygn. AAG, wiz. 72, s. 432.

${ }^{41}$ Tamże.

${ }^{42}$ Tamże, s. 433. 
darząc te zgromadzenia wielką rewerencją. Proboszczowie macierzystej parafii w Grocholicach zmuszeni byli tolerować wizyty obcego duchowieństwa u siebie, obawiając się być może podjęcia prób zmierzających do utworzenia odrębnej parafii. Czasami dochodziło jednak do konfliktów kompetencyjnych. Najpoważniejszy miał miejsce podczas odpustu w dniu 8 września $1851 \mathrm{r}$. Ostrowscy zaprosili na uroczystości proboszcza z Kamieńska, który miał celebrować uroczystą mszę świętą oraz prowincjała bernardynów z Piotrkowa wraz kilkoma braćmi i dwóch franciszkanów (w tym gwardiana $z$ Piotrkowa). Proboszcz A. Kupczyński z Grocholic, który także był zaproszony do Łękawy, przybył spóźniony. Zdenerwował się bardzo, że odpust rozpoczęto nie czekając na jego przyjazd. Swojemu wielkiemu niezadowoleniu dał wyraz wobec gości i zebranych mieszkańców, oskarżając zakonników o wtrącanie się w sprawy jego parafii. Ksiądz z Kamieńska naraził się, ponieważ na odpust przybyli członkowie jednego z bractw kościelnych z tego miasteczka. Nie uspokoiły ks. Kupczyńskiego zapewnienia, że proboszcz sąsiedniej parafii nic nie wiedział o wizycie swoich parafian. Kilka przykrych słów usłyszał nawet dziedzic Ignacy Ostrowski. Po uroczystościach duchowni ochłonęli i poszli wszyscy na obiad do dworu. Proboszcz Kupczyński po całym zajściu wrócił do siebie i napisał skargę na proboszcza z Kamieńska do Konsystorza Foralnego Piotrkowskiego, sprawującego ogólny nadzór nad duchowieństwem parafialnym ${ }^{43}$.

Kolejnym źródłem konfliktu z kolatorami kaplicy w Łękawie, była sprawa interpretacji przywileju na odprawianie mszy świętych. Indult papieski dawał prawo odprawiania w Łękawie mszy w niedziele oraz pomniejsze święta kościelne, za wyjątkiem Wielkanocy, Matki Bożej Szkaplerznej, rocznicy poświęcenia kościoła w Grocholicach oraz Wszystkich Świętych. O ile Spinkowie starali się postępować w granicach prawa, to ich spadkobiercy, Wiktoria i Ignacy Ostrowscy, nie mieli takich skrupułów. Jesienią $1856 \mathrm{r}$. ks. A. Kupczyński poskarżył się oficjalnie Konsystorzowi w Piotrkowie, który dokonał wizytacji kaplicy w Łękawie i przesłuchał tamtejszego kapelana o. Barnabę Pełkę, bernardyna z Piotrkowa ${ }^{44}$. Odpierając zarzuty, kapelan oznajmił, że ściśle przestrzega porządku mszy św. określonego w przywileju i wszystko jest zgodne z dotychczasowym porządkiem. Tymczasem dziedzic Ostrowski w liście skierowanym do Konsystorza napisał, że celebrowana jest msza św. w odpust patronki kaplicy, w święto Narodzenia NMP. Co ciekawe, proboszcz Kupczyński miał uczestniczyć w uroczystościach w roku 1850 i 1851 . Ostrowski szukając rozwiązania sporu z macierzystą parafią proponował przekazanie kaplicy w zarząd proboszcza w Kamieńsku, na co nie zgodziły się władze duchowne. Aby zalegalizować dodatkowy odpust, za radą Konsystorza, Ostrowski wystąpił do Stolicy Apostolskiej o stosowny przywilejej.

Najpełniejszy opis kościoła z początkowego okresu zaborów pochodzi z protokołu wizytacji kanonicznej przeprowadzonej 5 listopada 1811 r. przez ostatniego opata witowskiego, ks. Wojciecha Kamińskiego ${ }^{46}$. Funkcję proboszcza pełnił

\footnotetext{
${ }^{43}$ AAŁ, Konsystorz Foralny Piotrkowski (dalej: KFP), sygn. 74.

${ }^{44}$ Tamże.

${ }^{45}$ Tamże.

${ }^{46}$ ADW1, Visitationes, sygn. AAG, wiz. 135, s. 191-202.
} 
przynajmniej od roku 1802 ks. Tomasz Stanisław Kostka Kafarski, wyświęcony w 1776 r. Już na początku lustracji zwracano uwagę na niebezpieczeństwo pożaru kościoła wynikające $\mathrm{z}$ jego centralnego położenia w mieście ${ }^{47}$. Kilkanaście kroków od ogrodzenia przykościelnego cmentarza znajdował się ratusz miejski oraz zabudowania mieszczan, w znacznej części drewniane. O tym, że było to zagrożenie realne świadczyły pożary, w których kościół ucierpiał w przeszłości, np. w 1626, czy też w 1781 r. Po tym ostatnim pożarze, remont zniszczonego obiektu trwał kilka lat. Nowością w świątyni były dwa murowane groby usytuowane wewnątrz prezbiterium, dobrze zabezpieczone. Pozostałe elementy wyposażenia wnętrza nie zmieniły się od lat ${ }^{48}$.

W archiwum parafialnym przechowywano 8 ksiąg metrykalnych do zapisywania aktów ochrzczonych, zaślubionych i zmarłych, prowadzone od roku 1716. Ponadto wizytator wyliczył cztery pozycje zawierający opisy uposażenia parafii oraz przywilejów, w tym Liber beneficiorum Jana Łaskiego, akt erekcyjny konfraterni Szkaplerza Świętego z 1680 r., oraz przywilej arcybiskupa Ignacego Krasickiego z 1796 r. darujący kościołowi w Grocholicach osadę wójtowską w tym mieście. Poza kilkoma mszałami i księgą zarządzeń władz kościelnych nie było żadnej biblioteki podręcznej ${ }^{49}$. Według rejestru dusz, cała parafia liczyła 1262 osoby, co nie zgadzało się z wyliczeniami komunikowanych parafian ${ }^{50}$. Najprawdopodobniej były to dane nieaktualne, albo też niedokładne.

Tabela 2. Liczba komunikujących się parafian w 1811 r.

\begin{tabular}{|c|c|c|}
\hline Lp. & Nazwa miejscowości & Liczba komunikowanych \\
\hline 1 & Grocholice & 354 \\
\hline 2 & Bełchatów & 92 \\
\hline 3 & Zdzieszulice & 132 \\
\hline 4 & Politanice & 77 \\
\hline 5 & Zawadów & 140 \\
\hline 6 & Wólka Łękawska & 110 \\
\hline 7 & Lękawa & 210 \\
\hline 8 & Rząsawa & 62 \\
\hline 9 & Kałduny & 67 \\
\hline 10 & Binków & 73 \\
\hline 11 & Czaplenice (Czapliniec) & 43 \\
\hline 12 & Bełchatówek & $\mathbf{1 3 9 3}$ \\
\hline & Razem & . \\
\hline
\end{tabular}

Źródło: ADWł, Visitationes ecclesiarum archidiaconatus unieioviensis, sygn. AAG, wiz. 135.

Wydaje się też, że zdecydowanie niewielka liczba komunikowanych z Bełchatowa, wskazuje na to, że część mieszkańców komunikowała się w kościele

\footnotetext{
${ }^{47}$ Tamże, s. 192.

${ }^{48}$ Tamże.

${ }^{49}$ ADW1, Visitationes, sygn. AAG, wiz. 135, s. 194.

${ }^{50}$ Tamże, s. 195.
} 
franciszkańskim, a reszta należała do innych wyznań, tj. Żydów i ewangelików. Według danych pochodzących z 1832 r. w Bełchatowie zamieszkiwało 810 katolików i 74 Żydów. Brakuje danych o liczbie ewangelików, ale wydaje się, że mogło ich być kilkadziesiąt osób. W roku 1811 na terenie całej parafii naliczono ok. 100 ewangelików i 400 Żydów ${ }^{51}$.

Odpusty zwyczajne celebrowano trzy razy w roku: na Wszystkich Świętych, Matki Bożej Szkaplerznej i na św. Mikołaja. Msze św. w niedziele i święta rozpoczynały się rano o godzinie $7 .^{52}$ Poza dochodami z posiadanych gruntów, proboszcz czerpał dochody z dziesięciny, która nie przekraczała wtedy 254 zł rocznie. ${ }^{53}$ Jak pisze A. Kowalczyk, w 1809 r. nowy właściciel Bełchatowa, Leon Kaczkowski doprowadził do krótkotrwałego wydzielenia nowej parafii Bełchatów, z kościołem franciszkanów pełniącym funkcje fary ${ }^{54}$. W $1810 \mathrm{r}$. dziedzic Bełchatowa i kilku okolicznych wiosek zaprzestał wszelkich opłat na rzecz parafii w Grocholicach, co naraziło ją na stratę ok. 62 zł. Ogólnie dochody proboszcza, za wyjątkiem wpływów z posługi obliczano na 576 zł..$^{55}$

Razem z kościołem, z polecenia arcybiskupa Michała Poniatowskiego, przed 1794 r. wyremontowano budynek szpitala, który posiadał cztery izby. W jednej z nich mieszkał organista z żoną i dziećmi, a w drugiej sześciu ubogich utrzymujących się z jałmużny. Szpital nie posiadał już żadnych osobnych dochodów. Na utrzymanie organisty zabezpieczono kwotę 800 zł rocznie, natomiast na szkółkę parafialną i nauczyciela (bakałarza) było zaledwie $40 \mathrm{zł}$, co nie wystarczało na wynajem osobnego pomieszczenia szkolnego ani też na zatrudnienie nauczycie$1 a^{56}$. Sytuacja w tej kwestii była zła już sto lat wcześniej ${ }^{57}$, co wykazywał ks. Mateusz Chelmicki wizytujący Grocholice w 1729 r. Pieniądze na szkołę pobierał organista, który uczył dzieci (wyłącznie chłopców). Nie była to nauka regularna, ponieważ trwała od św. Marcina (11 listopada) do św. Wojciecha, gdy dzieci nie

${ }^{51}$ Tamże, s. 196.

${ }^{52}$ Tamże, s. 197.

${ }^{53}$ ADW1, Visitationes, sygn. AAG, wiz. 135, s. 198.

${ }^{54}$ Powstanie nowej parafii w Bełchatowie dotyczyło nie tylko parafii w Grocholicach, na terenie której leżał Bełchatów ale także do parafii w Bogdanowie i Parznie, od których miały zostać odłączone niektóre miejscowości. Projekt spotkał się z silnym sprzeciwem proboszczów parafii, które miały zostać uszczuplone terytorialnie. Zob. Archiwum Państwowe w Łodzi (dalej: APŁ), Rząd Gubernialny Piotrkowski. Anteriora (dalej: RGPA), sygn. 2075.

${ }^{55}$ ADWł, Visitationes, sygn. AAG, wiz. 135, s. 199.

${ }^{56}$ Tamże, s. 201.

${ }^{57}$ Warunki panujące w szkole parafialnej w Grocholicach nie wyróżniała się na tle innych tego typu placówek funkcjonujących w Rzeczypospolitej, gdzie nauczycielami byli organiści, a chłopców przyuczano do służby kościelnej. Program nauki obejmował znajomość pisania i czytania, czasami podstaw rachunków oraz poznanie podstawowych prawd wiary. Pod koniec XVIII w. pod wpływem działań podejmowanych przez Komisję Edukacji Narodowej, do szkół parafialnych w szerszym stopniu zaczęto przyjmować dziewczęta. Ks. L. Jażdżewski zajmujący się szkolnictwem kościelnym na Pomorzu, podaje, że z kościelnych placówek oświatowych już wcześniej mogły korzystać dzieci obojga płci, a nawet sporadycznie, różnych wyznań. Por. L. Jażdżewski, Szkolnictwo parafialne na obecnym obszarze archidiecezji gdańskiej w okresie staropolskim „Studia Gdańskie”, 37 (2015) s. 235-250. 
musiały pracować w polu i miały czas wolny. Program nauczania obejmował jedynie czytanie i pisanie ${ }^{58}$.

Po śmierci proboszcza ks. Kafarskiego, w dniu 17 września 1813 r. administratorem parafii w Grocholicach został ks. Patrycy Jankowski, który w sierpniu 1821 r. został odwołany i zastąpił go ks. Kajetan Ungier ${ }^{59}$. Kapłan ten zmuszony był uregulować sprawy związane $\mathrm{z}$ utrzymaniem majątku parafialnego, uszczuplanego przez nieuczciwych dzierżawców gruntów. Do sądu trafiła sprawa ziemi przywłaszczonej sobie przez mieszczanina Bogumiła Hartmanna, który nie chciał jej zwrócić. Koszty sądowe stanowiły poważne obciążenie budżetu parafialnego. Kolejnym problemem, z którym się ks. Ungier borykał był osobisty spór finansowy z poprzednim proboszczem, ks. Jankowskim. Takie sytuacje miały miejsce także w innych miejscowościach, jednak kładły się cieniem na dobry wizerunek Kościoła. Problemy finansowe wstrzymywały decyzje związane z remontami i bieżącym utrzymaniem kościoła i innych nieruchomości parafialnych.

W 1830 r. stan techniczny kościoła grocholickiego uległ znacznemu pogorszeniu. W opisach kościołów dekanatu piotrkowskiego, zapisano, że wprawdzie pewne prace remontowe przeprowadzono kilka lat wcześniej (nie sprecyzowano dokładnie co udało się zrobić), to i tak było jeszcze wiele potrzeb. Należało przede wszystkim wymienić zgnite poszycie dachowe i położyć nową dachówkę (gonty). Pilnej naprawy wymagała też wieża kościelna, a dokładniej przeciekająca kopu$\nmid \mathrm{a}^{60}$. Widziano też potrzebę założenia nowego cmentarza, ponieważ stare miejsce pochówków wokół kościoła było przepełnione. Nie można go było poszerzyć ze względu na stojące w pobliżu zabudowania mieszkalne i gospodarcze ${ }^{61}$.

Tabela 3. Ludność Grocholic pod względem wyznania w latach 1832-1859

\begin{tabular}{|c|c|c|c|c|}
\hline Rok & Katolicy & Ewangelicy & Żydzi & Razem \\
\hline 1832 & 810 & - & 74 & 884 \\
\hline 1842 & 1095 & 55 & 118 & 1268 \\
\hline 1852 & 1123 & 93 & 152 & 1368 \\
\hline 1859 & 1103 & 94 & 151 & 1348 \\
\hline
\end{tabular}

Źródło: Źródła do historii miast łódzkiego okręgu przemysłowego $w$ XIX w., oprac. R. Kaczmarek, Warszawa 1958, s. 251; Opis miasta sporządzony przez burmistrza Franka, Grocholice $31.05 .1860 \mathrm{r}$.

Nieco inne dane dotyczące preferencji wyznaniowych mieszkańców samych Grocholic a także całej parafii pochodzą z 1835 r. Wynika z nich, że miasteczko zamieszkiwało 835 katolików, 28 ewangelików oraz 75 wyznawców judaizmu. Na terenie parafii odnotowano 2593 katolików, 516 ewangelików i 488 Żydów ${ }^{62}$.

${ }^{58}$ ADW1, Visitationes, sygn. AAG, wiz. 13, k. 144.

${ }^{59}$ AAŁ, KFP, sygn. 73.

${ }^{60}$ Archiwum Państwowe w Piotrkowie (dalej: APPT), Akta Dziekana Piotrkowskiego (dalej: ADP), sygn. 44.

${ }^{61}$ Tamże.

${ }^{62}$ APł, RGPA, sygn. 2075, s. 314-316. 
Zgodnie z przepisami dziekani piotrkowscy przeprowadzali wizytacje podległych sobie parafii raz w roku. W zasobie Archiwum Państwowego w Piotrkowie Trybunalskim znajduje się kilka protokołów dziekańskich. Pierwsza z przywołanych kontroli miała miejsce 4 lutego 1833 r., w czasie gdy proboszczem był ks. Andrzej Kupczyński, mający 32 lata $^{63}$. Swoje obowiązki zmuszony był wykonywać samodzielnie, gdyż parafia nie miała funduszy na utrzymanie wikariusza. Zaledwie rok wcześniej (wiosną 1832 r.) zastapił on zmarłego proboszcza Kajetana Ungiera. Do tego czasu pełnił posługę wikariusza w miasteczku Chodzież. W trakcie wprowadzania nowego kapłana na probostwo, sporządzono inwentarz zawierający opis wszystkich nieruchomości i ruchomości parafialnych. Kilka lat wcześnie, w trakcie powstania listopadowego (1831) władze zarekwirowały dwa popsute dzwony, które przetopiono na armaty. Dwa pozostałe dzwony zawieszono wtedy na lipie, ponieważ nie było środków na odbudowanie zniszczonej dzwonnicy. ${ }^{64}$

Obraz budynku świątyni jaki się wyłaniał z protokołu ks. dziekana z roku 1833 nie napawał optymizmem. Wymagał wymiany dachu i okien oraz reparacji zniszczonego muru wokół kościoła. Zarówno trzy ołtarze, jak i wyposażenie utrzymane były w dobrym stanie. Inwestycji nie wymagał też nowy cmentarz na Zamościu otoczony drewnianym parkanem. $\mathrm{Na}$ środku cmentarza stała figura Męki Pańskiej ${ }^{65}$.

Proboszcz oprócz obowiązków związanych z posługą duchowną, prowadził też raz $\mathrm{w}$ tygodniu lekcję religii $\mathrm{w}$ miejscowej szkole elementarnej. Poza tym utrzymywał szpital dla ubogich parafian. Ze względu na to, że w budżecie parafii nie było środków na mieszkanie dla organisty Stanisława Gaudynowskiego, lokal dla niego zakupił proboszcz na terenie miasta.

W złym stanie znajdowała się też drewniana plebania oraz pięć innych zabudowań parafialnych. W zasadzie stodołę, stajnię i oborę należało rozebrać i postawić od nowa. Ksiądz robił co mógł by budowle te się nie zawaliły, lecz na nowe nie miał pieniędzy. Majątek kościoła składał się głównie z piaszczystych gruntów ornych i pastwisk - ok. 110 mórg oraz wpływów z dziesięciny (ok. 250 zł rocznie) i procentów od kapitałów własnych zapisanych na hipotekach (ok. 84 zł rocznie).

Kolejna wizytacja, którą przeprowadzono w marcu 1840 r. wykazała, że stan kościoła grocholickiego nie uległ poprawie ${ }^{66}$. Zmienił się organista - St. Gaudynowskiego zastąpił Jan Świątkowski. W 1842 r. nastąpiła kolejna zmiana na tym stanowisku - organistą został Stanisław Grotowski ${ }^{67}$. Nadzór budowlany nakazał księdzu rozbiórkę zdezelowanych obiektów gospodarczych, ponieważ groziły zawaleniem, czego ten nie wykonał. Ks. Kupczyńskiemu udało się odbudować młyn oraz postawić małą stodółkę i obórkę. We młynie mielono ziarno na mąkę oraz wytwarzano kaszę. Dodatkowo urządzono olejarnię. Proboszcz ogrodził też pło-

\footnotetext{
${ }^{63}$ APPT, ADP, sygn. 44

${ }^{64}$ APPT, ADP, sygn. 44.

${ }^{65}$ Tamże.

${ }^{66}$ APPT, ADP, sygn. 43.

${ }^{67}$ Tamże, sygn. 45.
} 
tem podwórze wokół plebanii. ${ }^{68} \mathrm{~W}$ roku 1841 ks. Kupczyński zdobył fundusze na wymianę gontów na kościele (ok. 3500 zł). Prace rozłożono na kilka lat (zakończono je w 1844 r.). Znaczną część niezbędnych remontów kościoła proboszcz sfinansował z prywatnych dochodów ${ }^{69}$.

W 2. połowie XIX w. poprawiła się kondycja finansowa parafii dzięki odkryciu jakiego dokonał proboszcz Kupczyński. W bliżej nieznanych okolicznościach dowiedział się, że w testamencie z dnia 2 grudnia 1800 r. dziedzic dóbr Kamieńsk i Łękawa, Daniel Józef Spinek, zapisał kościołowi w Grocholicach 1800 zł $^{70}$. Nie określił jednak warunków na jakich można korzystać z pieniędzy. Darowizna wpisana została do hipoteki Kamieńska, z oprocentowaniem rocznym wynoszącym $5 \%$. Przez kilkadziesiąt lat parafia nie korzystała z zapisu. W połowie lat 40 . XIX w. władze przeprowadziły dochodzenie, kto pobierał procenty i na jaki cel je przeznaczył. Spadkobiercy zmarłego, syn Wojciech, a po nim Albert Spinek nie śpieszyli się jednak ze spłatą zaległych odsetek. W połowie lat 30. XIX w. majętności Spinków przeszły drogą dziedzictwa na spokrewnioną z tą rodziną Wiktorię Ostrowską z Piaszczyc koło Radomska, żonę Ignacego Ostrowskiego. Oni także nie zamierzali się wywiązywać z dawnych zobowiązań finansowych i sprawę ok. 1840 r. skierowano na drogę sądową. Korzystne dla kościoła postanowienia sądowe zapadły dopiero po długim i kosztownym procesie trwającym $20 \mathrm{lat}^{71}$.

Obok kościoła parafialnego w Grocholicach w okresie staropolskim egzystowała jeszcze jedna świątynia. Drugi kościół wykonany z drewna miał się znajdować według wizytatora Wilkoszowskiego z 1636 r., za miastem, od wschodniej strony. Także ks. Franciszek Grochowalski, który wizytował Grocholice w 1779 r. wskazywał na tę lokalizację ${ }^{72}$. Inne źródła podają odmienną lokalizację - według nich świątynię wybudowano na południowym przedmieściu Grocholic ${ }^{73}$. Kościół fundowany najpewniej w XVI stuleciu, był pw. św. Jana Chrzciciela. W późniejszych opisach pojawia się jeszcze druga tytulatura - św. Jana Chrzciciela i św. Doroty). Kościół był konsekrowany, a pamiątkę tego wydarzenia obchodzono co roku, w pierwszą niedzielę po dniu św. Jana Chrzciciela. Wewnątrz znajdowały się trzy ołtarze, z których chyba tylko główny posiadał portatyl (czyli uznawano go za poświęcony $)^{74}$. Źródło nie podaje tytulatury żadnego z nich. Można się jedynie domyślać, że ołtarz główny był pod wezwaniem patrona świątyni - św. Jana Chrzciciela. Wokół kościoła umiejscowiono cmentarz grzebalny (konsekrowany), zabezpieczony ogrodzeniem. W drewnianej dzwonnicy wisiały dwa dzwony ${ }^{75}$.

Świątynia ta pełniła okresowo funkcję pomocniczego kościoła parafialnego, co poświadczają historycy (np. ks. Stanisław Librowski określając ją mianem pre-

${ }^{68}$ Tamże.

${ }^{69}$ APŁ, RGPA, sygn. 2076.

${ }^{70}$ Testament został ogłoszony $18.12 .1805 \mathrm{r}$.

${ }^{71}$ AAŁ, KFP, sygn. 74.

${ }^{72}$ ADWł, Visitationes, sygn. AAG, wiz. 72, s. 434.

${ }^{73} \mathrm{~Np}$. protokół sporządzony przez archidiakona uniejowskiego Andrzeja Pruskiego w 1683 r. Zob. ADWł, Visitationes, sygn. AAG, wiz. 8, s. 126.

${ }^{74}$ Tamże.

${ }^{75}$ Tamże. 
pozytury symplicznej tzn. prostej $)^{76}$. Dodatkową wskazówką przemawiającą za takim statusem kościółka był fakt, potwierdzony już w 1636 r., że prowadzono w nim rejestry ksiąg metrykalnych (księgi chrztów i ślubów od 1598 r.) ${ }^{77}$. Posiadał też swoje beneficium (uposażenie w grunty uprawne). Do dobroczyńców kościoła św. Jana Chrzciciela należała też przedstawicielka lokalnego ziemiaństwa, Zofia Kowalewska, żona Mikołaja Kowalewskiego, fundatora klasztoru Franciszkanów w Bełchatowie. Kapelanem kościółka pw. św. Jana Chrzciciela był w 1683 r. ks. Jan Retkowicz (Retkiewicz) ${ }^{78}$.

Świątynia wykonana z drewna, narażona była szczególnie na zniszczenia wywołane przez pożary. Podczas wojny północnej ze Szwecją, jaka miała miejsce na początku XVIII w. została kompletnie zniszczona i ograbiona z całego wyposażenia. Wydaje się jednak, że zdołał podnieść się z ruin, pomimo że wizytacja z 1712 r. pomija ją milczeniem. Co więcej, pojawia się wtedy wzmianka o jeszcze innym kościele pw. Świętego Ducha ${ }^{79}$. Posiadał on tylko jeden ołtarz poświęcony św. Piotrowi Apostołowi. Drugą, a zarazem ostatnią wzmiankę o nim znajdziemy w protokole wizytacji przeprowadzonej w 1759 r. przez proboszcza z Ruśca, ks. Rafała Jarnowskiego ${ }^{80}$. Być może rozwikłanie tajemnicy tej świątyni leży w jednym zdaniu. Wizytator w 1712 r. informował, że kościółek był konsekrowany, pamiątkę tego faktu świętowano w pierwszą niedzielę po dniu św. Jana Chrzciciela, tak jak zapomniany kościół pw. św. Jana Chrzciciela i Doroty ${ }^{81}$. Prawdopodobnie $\mathrm{w}$ tym przypadku mamy do czynienia $\mathrm{z}$ tym samym obiektem występującym pod dwoma (a w zasadzie trzema) tytułami. Ks. Stanisław Librowski, który analizował protokoły wizytacyjne, w haśle poświęconym Grocholicom traktuje kościół szpitalny pw. Św. Ducha jako odrębny obiekt, wybudowany w 1562 r. i zniszczony podczas wielkiego pożaru w $1781 \mathrm{r}^{82}$ Kościoły poświęcone Duchowi Świętemu pełniły najczęściej funkcję kaplic szpitalnych i tak było tym razem. Wątpliwym wydaje się też by mniej więcej w tym samym czasie (1. połowa XVIII w.) istniały w Grocholicach aż dwie prepozytury szpitalne. Co charakterystyczne, w żadnym protokole wizytacyjnym oba te kościoły (św. Jana Chrzciciela i Św. Ducha) nie wystąpiły jednocześnie, a tak by przecież było gdyby istniały jako dwa różne obiekty.

W protokole z 1729 r. opisano krótko szpital, czyli przytułek dla biednych kobiet i mężczyzn (położony przy drodze do Bełchatowa) oraz wspomniano, że

${ }^{76}$ S. Librowski, Repertorium akt wizytacji kanonicznych dawnej archidiecezji gnieźnieńskiej. Akta przechowywane w Archiwum Diecezjalnym we Włocławku, Lublin 1975, s. 97.

${ }^{77}$ ADW1, Visitationes, sygn. AAG, wiz. 5, s. 181-182.

${ }^{78}$ ADW1, Visitationes, sygn. AAG, wiz. 8, s. 126.

${ }^{79}$ Autorzy inwentarza topograficznego opisującego zabytki powiatu piotrkowskiego (wyd. Warszawa 1950) podają błędnie, że pierwsza wzmianka o kościele Św. Ducha pojawiła się w protokole wizytacyjnym z 1683 r. Por. Zabytki sztuki w Polsce. Inwentarz topograficzny. Powiat Piotrkowski. Praca zbiorowa uczestników obozu naukowego w Sulejowie k. Piotrkowa, Warszawa 1950, s. 92.

${ }^{80}$ ADW1, Visitationes, sygn. AAG, wiz. 41, s. 15.

${ }^{81}$ ADW1, Visitationes, sygn. AAG, wiz. 9, s. 455.

${ }^{82}$ Librowski, Repertorium akt wizytacji kanonicznych, s. 97. 
w Grocholicach funkcjonuje kościół szpitalny pw. św. Jana Chrzciciela i Doroty ${ }^{83}$. Kompletny remont (przede wszystkim nowe pokrycie dachowe) przeprowadził proboszcz, ks. dziekan Jan Kuciński ${ }^{84}$. Dzięki jego zapobiegliwości zabytkowa budowla istniała jeszcze w 1765 r. (określona mianem prepozytury szpitalnej), choć znajdowała się w bardzo złym stanie technicznym ${ }^{85}$. Obawiano się, że w krótkim czasie zgnije doszczętnie i nie pozostanie po niej żaden ślad. Tak też się stało, ponieważ w 1779 r. ks. Grochowalski wspomina o nim jako o nieistniejącym $^{86}$. Mało prawdopodobne, ale hipotetycznie możliwe, że zrujnowany kościół padł ofiarą wielkiego pożaru z $1781 \mathrm{r}$. W każdym razie wizytator, który odwiedził Grocholice w 1788 r. zapisał jedynie informacje na temat kościoła farnego, co zdaje się wskazywać niezbicie, że drewniana świątynia szpitalna przestała istnieć $^{87}$. Ziemie należące do uposażenia kościoła przejął proboszcz. Prawie sto lat później, w 1861 r., w protokole przekazania obowiązków nowemu proboszczowi Teodorowi Głuchowskiemu zapisano, że w miejscu, w którym przez kilkaset lat stał drewniany kościółek, wybudowano później drewniane czworaki (budynek mieszkalny) dla kościelnych wyrobników ${ }^{88}$.

W długich dziejach Grocholic było przynajmniej pięć cmentarzy parafialnych. Dwa najstarsze zlokalizowane były pradawnym zwyczajem wokół kościołów pełniących funkcje świątyń parafialnych - wokół fary przy Rynku (pw. Wszystkich Świętych) oraz wokół drewnianego kościółka pw. św. Jana Chrzciciela. Ten ostatni zanikł po dewastacji kościoła w 2. połowie XVIII w. Natomiast pochówków wokół fary zaniechano z przyczyn administracyjnych oraz sanitarnych, najprawdopodobniej w połowie XIX w. Jeszcze wiele lat później ludzie nazywali plac przykościelny używając określenia „,cmentarz”.

Na stronie internetowej kościoła w Grocholicach, znajduje się zakładka poświęcona cmentarzom ${ }^{89}$. Według autora (autorów) krótkiej notatki były trzy miejsca pochówku zmarłych. Pierwszy cmentarz miano założyć w 1810 r., w miejscu niespecjalnie nadającym się do tego celu, gliniastym i podmokłym (przy obecnej ul. Szkolnej). W sumie spoczęło na nim 637 osób (ostatnim był Sebastian Skalski z Grocholic, pochowany 2 maja 1822 r.). Zamknięty cmentarz miał się znajdować w okolicach dzisiejszej ulicy Szkolnej. W materiałach opracowanych do katalogu diecezjalnego na 1936 r. zapisano, że nieużywany od kilkudziesięciu lat cmentarz był niewielki, liczył $1006 \mathrm{~m}^{2}$ i otoczony był rowem ${ }^{90}$. Zastanawiające, że ks. Wojciech Kamiński (ostatni opat klasztoru witowskiego) wizytujący Grocholice w $1811 \mathrm{r}$. milczał na temat nowego miejsca grzebania zmarłych parafian. Wspominał jedynie czynny cmentarz przykościelny ${ }^{91}$.

\footnotetext{
${ }^{83}$ ADW1, Visitationes, sygn. AAG, wiz. 13, k. 144.

${ }^{84}$ ADWł, Visitationes, sygn. AAG, wiz. 59, s. 131.

${ }^{85}$ Tamże.

${ }^{86}$ ADWł, Visitationes, sygn. AAG, wiz. 72, s. 432.

${ }^{87}$ ADWł, Visitationes, sygn. AAG, wiz. 81, s. 1-18.

${ }^{88}$ AAŁ, KFP, sygn. 74, k. 280.

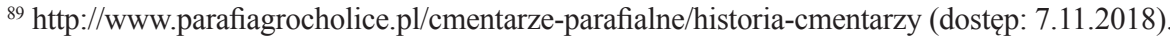

${ }^{90}$ AAŁ, AKŁ, sygn. 51.

${ }^{91}$ ADWł, Visitationes ecclesiarum archidiaconatus unieioviensis, sygn. AAG, wiz. 135.
} 
Drugi cmentarz założono w $1822 \mathrm{r}$. w miejscu piaszczystym, położonym przy drodze do Bełchatowa (Zamoście, dzisiejsza ul. Wojska Polskiego). W 1878 r. został powiększony. Przed wybuchem drugiej wojny światowej obejmował 1,14 ha i od frontu ogrodzony był ceglanym murem, z pozostałych stron ocynkowaną siatką. Pochowano na nim kilku poległych powstańców styczniowych z $1863 \mathrm{r}$.

Trzeci cmentarz powstał w 1894 r. za miastem (obecna ul. Tylna), choć pierwszy pochówek miał miejsce dopiero w 1901 r. (Ignacy Widlicki z Grocholic). Cmentarz powiększano w 1934 i 1963 r., tak, że dzisiaj obejmuje ponad 2 ha. Pochowano na nim m.in. żołnierzy polskich poległych w wojnie obronnej $1939 \mathrm{r}$. (obrońcy Gór Borowskich).

Druga połowa XIX w. postawiła wobec grocholickiego kościoła i jego proboszczów zasadniczy dylemat. Wobec wzrostu liczby ludności, a tym samym i parafian, należało rozstrzygnąc kwestię rozbudowy, bądź budowy od podstaw nowej świątyni. Na przeszkodzie tym planom stanęły nie władze, ani też obrońcy zabytków lecz miejscowi parafianie, którzy przyzwyczaili się do wyglądu swojego kościoła i nie mieli zamiaru go niszczyć czy zmieniać. Być może obawiali się też kosztów, które obciążałyby ich kieszenie w związku z realizacją inwestycji. Po wieloletnich staraniach, w roku 1897 ks. Franciszek Zając zburzył zabytkową farę i wzniósł w jej miejsce całkiem nowy obiekt, o założeniu neogotyckim ${ }^{92}$. Tym samym, symbolicznie, w dziejach parafii rozpoczął się nowy okres.

\section{Źródla}

\section{REFERENCES / BIBLIOGRAFIA}

Archiwum Archidiecezjalne w Łodzi (AAŁ)

Akta Kurii Łódzkiej:

Akta parafii Bełchatów-Grocholice, sygn. 51

Konsystorz Foralny Piotrkowski:

Akta dotyczące parafii Grocholice, sygn. 73

Akta tyczące się kościoła parafialnego w Grocholicach, sygn. 74

Archiwum Diecezjalne we Włocławku (ADWł)

Acta visitationis totius archidiaconatus unieioviensis... per Lucam Wilkoszewski archidiaconum unieioviensis, canonicum gnesnensis et parochum koninensis ... in Anno Domini MDCXXXVI feliciter expeditae, sygn. AAG, wiz. 5

Acta visitationis archidiaconatus unieioviensis... per Andream Pruski ... in 1683 tio feliciter expeditae, sygn. AAG, wiz. 8

Acta visitationis beneficiorum curatorum et simplicium in archidiaconatu unieioviensi ... per Alexandrum Proszewski archidiaconum unieioviensis Anno Domini MDCCXI et MDCCXII expeditae, Visitatio ecclesiae parochialis in Grocholice, sygn. AAG, wiz. 9

${ }^{92}$ Autorem koncepcji architektonicznej był piotrkowski architekt Korneliusz Szretter oraz architekt gubernialny Feliks Nowicki. Ten ostatni zaprojektował kilka kościołów w stylu neogotyckim, wybudowanych przed 1914 r. w Milejowie, Parznie i Sulejowie. 
Liber visitationis ecclesiarum archidiaconatus unieioviensis ... per Mathiam Chełmicki ... expeditae, Visitatio ecclesiae parochialis in Grocholice expedita [in] 1729, sygn. AAG, wiz. 13

Visitatio decanalis ecclesiarum decanatus schadkoviensis ... per me Raphaelem Jarnowski expedita, sygn. AAG, wiz. 41

Opus biennale visitationum archidiaconatus unieioviensis ... per Franciscam Grochowalski [in] 1765 [expedita], sygn. AAG, wiz. 59

Wizyta generalna trzech dekanatów Szadkowskiego, wartskiego i uniejowskiego ... przez księdza Franciszka Xawerego Grochowalskiego obojga prawa doktora ... delegowanego wizytatora Roku Pańskiego 1779 tego, sygn. AAG, wiz. 72

Visitatio decanalis ecclesiarum parochialum et capellarum ... in decanatu schadkoviensi archidiaconatus unieioviensis existentium ... per nos [Joannus Pauli Rachlewski] descripta et expedita, sygn. AAG, wiz. 81

Status ecclesiarum et beneficiorum in decanatibus szadkoviensi et lutomiriensi ... per Adalbertum Kamiński ... expedita, Kościół parafialny w miasteczku narodowym Grocholicach ... podany do opisu podczas wizytacji kanonicznej roku 1811 dnia 5 listopada, sygn. AAG, wiz. 135

Archiwum Państwowe w Łodzi (APŁ)

Rząd Gubernialny Piotrkowski. Anteriora

Akta probostwa w mieście Grocholicach, sygn. 2075

Akta w przedmiocie probostwa w mieście Grocholicach, sygn. 2076

Archiwum Państwowe w Piotrkowie Trybunalskim

Akta Dziekana Piotrkowskiego:

Wizyta dekanalna periodyczna kościoła parafialnego w mieście Grocholicach za rok 1839, sygn. 43

Protokół z wizytacji odbytej przez dziekana dekanatu piotrkowskiego w mieście Grocholicach, sygn. 44

Wizyta dekanalna periodyczna kościoła parafialnego w mieście Grocholicach za rok 1841, sygn. 45

Łaski J., Liber beneficiorum, t. 1, Gniezno 1880

Regesty wybranych zapisek z akt działalności arcybiskupów gnieźnieńskich, wyd. ks. H. Rybus „Archiwa, Biblioteki i Muzea Kościelne”, 3 (1961) z. 1-2, s. 111-404.

Wizytacje dóbr arcybiskupstwa gnieźnieńskiego i kapituly gnieźnieńskiej $w$ XVI wieku, wyd. B. Ulanowski, Kraków 1920

Źródła do historii miast łódzkiego okręgu przemysłowego w XIX w., oprac. R. Kaczmarek, Warszawa 1958

\section{Opracowania}

Abraham W., Organizacja kościoła w Polsce do połowy XII wieku, Lwów 1890.

Dobrowolski K., Znaczenie metryk kościelnych dla badań naukowych, „Rocznik Towarzystwa Heraldycznego", 5 (1920) s. 90-110.

Hamryszczak A., Canonical visitations as a historical source, „Archiwa, Biblioteki i Muzea Kościelne", 105 (2016) s. 53-62.

Jażdżewski L., Szkolnictwo parafialne na obecnym obszarze archidiecezji gdańskiej w okresie staropolskim „Studia Gdańskie”, 37 (2015) s. 235-250.

Korytkowski J., Arcybiskupi gnieźnieńscy, prymasowie i metropolici polscy, t. I, Poznań 1888. 
Kufel R., Kancelaria, registratura i archiwum parafialne na ziemiach polskich od XII do poczatku XXI wieku, Zielona Góra 2011.

Librowski S., Repertorium akt wizytacji kanonicznych dawnej archidiecezji gnieźnieńskiej. Akta przechowywane w Archiwum Diecezjalnym we Włocławku, Lublin 1975.

Ordo divini officii ad usum dioecesis vladislaviensis seu calissiensis, Warszawa 1878.

Różański M., Duchowieństwo parafialne archidiakonatu uniejowskiego w XVIII wieku. Studium prozopograficzne, Łódź 2010.

Różański M, Szkoły parafialne w XVI-XVIII wieku w archidiakonacie uniejowskim, Łódź 2003.

Słownik geograficzny Królestwa Polskiego i innych krajów słowiańskich, red. F. Sulimierski, B. Chlebowski, W. Walewski, t. 2, Warszawa 1881.

Umiński J., Arcybiskup Wincenty z Niałka, następca Henryka, zw. Kietliczem, w: Księga pamiatkowa ku czci Władysława Abrahama, t. 2, Lwów 1931.

Wilk-Woś Z., Nie tylko dla genealogów - akta metrykalne w Archiwum Archidiecezjalnym w Łodzi jako źródło do badań historycznych, „Prace i Materiały Historyczne Archiwum Archidiecezjalnego w Łodzi i Muzeum Archidiecezji Łódzkiej”, 9 (2012) s. 123-135;

Wiśniowski E., Badania nad początkami i rozwojem średniowiecznej sieci parafialnej na ziemiach polskich, „Annales Universitatis Mariae Curie-Skłodowska Lublin - Polonia”, 45 (1990) s. s. 43-55.

Zabytki sztuki w Polsce. Inwentarz topograficzny. Powiat Piotrkowski. Praca zbiorowa uczestników obozu naukowego w Sulejowie k. Piotrkowa, Warszawa 1950.

\title{
Netografia
}

https://www.familysearch.org/ark:/61903/3:1:3Q9M-CSXK-Q9FL-K?i=716\&cat=299028

(dostęp: 13.11.2018)

http://www.fara-belchatow.pl/historia-parafii (dostęp: 14.11.2018)

http://www.parafiagrocholice.pl/cmentarze-parafialne/historia-cmentarzy (dostęp: 7.11.2018)

\section{THE PARISH OF ALL SAINTS AND THE IMMACULATE CONCEPTION OF THE BLESSED VIRGIN MARY IN GROCHOLICE IN THE LIGHT OF CANONICAL VISITATION}

\begin{abstract}
The Parish in Grocholice is one of the oldest in the Archdiocese of Łódź and is among the older ones in the whole Poland. It is assumed that the Parish of All Saints and the Immaculate Conception of the Blessed Virgin Mary was erected around 1230 by the then Archbishop of Gniezno, Wincenty of Niałek, Jelen coat of arms. The oldest preserved documents from the visitation of the parish in Grocholice are kept in the Diocesan Archives in Włocławek and come from 1636 and 1683. The materials from the 17th, 18th and the first half of the 19th century were used in this study. The original church was built from field stones and bricks around 1233. The historic church was pulled down at the beginning of the 20th century and a new neo-Gothic building was erected in its place.
\end{abstract}

Keywords: Bełchatów; Grocholice; parish; visitations; Archdiocese of Łódź 